\title{
Uwagi o ekwiwalencji słów kluczowych w systemie informacyjnym iSybislaw (na przykładzie wybranych terminów gramatycznych)
}

Ilość informacji - w tym również informacji naukowej - w ciągu ostatnich dziesięcioleci wzrosła lawinowo. Z wielu względów trudno dziś znać całą literaturę dotyczącą nawet ograniczonego zakresu tematycznego, którym zajmują się poszczególni językoznawcy, a tym bardziej całą slawistyczną produkcję językoznawczą. Coraz większa liczba wydawnictw publikujących literaturę językoznawczą w Polsce (również w innych krajach słowiańskich), powoduje, że nie tylko literatura, lecz także wiedza o niej nie zawsze jest dostępna. Obieg informacji naukowej, który jeszcze niedawno odbywał się głównie w postaci pisanej (bibliografii drukowanych), współcześnie odbywa się w coraz większym stopniu za pomocą Internetu. Miejsce wcześniejszych tradycyjnych bibliografii w dobie nowych technologii i Internetu zajmują bazy danych dostępne online, udostępniane na zasadach Open Access. Ze względu na bardzo łatwy dostęp do Internetu i jego zawartości tworzenie profesjonalnych baz danych wymaga od ich twórców niezwykle świadomego i odpowiedzialnego podejścia do tego zadania. Użytkownik powinien otrzymać profesjonalną i adekwatną do współczesnego stanu wiedzy informację naukową.

Powyższe uwagi o charakterze ogólnym odnieść można również do bibliografii językoznawczych w ogóle i bibliografii slawistycznych w szczególności. 
Istnienie dobrej - profesjonalnej i stale aktualizowanej - bibliografii językoznawstwa slawistycznego jest niewątpliwie sprawą bardzo ważną. Zadania przekształcenia tradycyjnej drukowanej bibliografii językoznawstwa slawistycznego w nowoczesny system informacyjno-wyszukiwawczy podjęto się w 1993 r. w Centrum Slawistycznej Informacji Naukowej Instytutu Slawistyki PAN (CSIN) kierowanym przez dr Zofię Rudnik-Karwatową. Wynikiem dwudziestoletniej już działalności CSIN jest udostępniona użytkownikom od 2008 r. online Bibliograficzna baza danych światowego językoznawstwa slawistycznego iSybislaw (http://www.isybislaw.ispan. waw.pl; Bibliograficzna baza danych światowego językoznawstwa slawistycznego iSybislaw, b.d.). iSybislaw to pierwsze tak szeroko zakrojone przedsięwzięcie tego rodzaju. Problemy związane z budowaniem i funkcjonowaniem systemu przedstawiano m.in. na Międzynarodowych Kongresach Slawistów w Krakowie (1998) i Lublanie (2003), a ponadto już w ramach specjalnych bloków tematycznych na kolejnych kongresach. Na kongresie w Ochrydzie (2008) tematem bloku był Nowoczesny system informacji bibliograficznej językoznawstwa slawistycznego (teraźniejszość i przyszłość) ${ }^{1}$, a na kongresie w Mińsku (2013) - Języki informacyjno-wyszukiwawcze w systemie informacji slawistycznej iSybislaw: dziś i jutro ${ }^{2}$.

System iSybislaw, podobnie jak każda bibliografia, to uporządkowany zbiór dokumentów, dobranych według określonych kryteriów, spełniających określone zadania informacyjne. W odróżnieniu jednak od tradycyjnej bibliografii drukowanej daje on użytkownikowi zupełnie inne możliwości wyszukiwania informacji. Jest to wyszukiwanie (proste i złożone) w dużym zbiorze danych według różnych parametrów, m.in. takich jak osoba (autor, redaktor, edytor, tłumacz i in.), tytuł dokumentu, język dokumentu, rok wydania, klasyfikacja rzeczowa, a także słowa kluczowe. Jeśli opis dokumentu zawiera abstrakt lub adnotację (czasem w dwóch językach: języku obcym i polskim), możliwe jest wyszukiwanie tekstowe również $\mathrm{w}$ tym polu. W niektórych rekordach w polu LINK znajduje się bezpośrednie przekierowanie do tekstu dokumentu w formacie pdf znajdującego się na zewnętrznym wobec iSybislaw serwerze ${ }^{3}$. Pozwala to

1 Teksty wystąpień opublikowane zostały w czasopiśmie „Zagadnienia Informacji Naukowej", 2007, 2 (90), ss. 19-69.

2 Teksty wystąpień opublikowane zostały w kwartalniku „Slavia Orientalis”, 2013, nr 2 i nr 4 .

${ }^{3}$ Konkretne dokumenty mogą być umieszczane na serwerze iSybislaw, jednak ze względu na nieuregulowaną prawnie sprawę praw autorskich w chwili obecnej ten element systemu nie jest wykorzystywany. 
Iwona Łuczków Uwagi o ekwiwalencji słów kluczowych w systemie informacyjnym iSybislaw...

użytkownikowi zapoznać się z konkretnym tekstem. Liczba takich odnośników sukcesywnie będzie się zwiększać. Jednak żeby użytkownik mógł skorzystać ze wszystkich tych możliwości, baza danych musi być stale uzupełniana i aktualizowana, a system udoskonalany ${ }^{4}$.

Celu niniejszego artykułu nie stanowi szczegółowe omówienie systemu iSybislaw. Odpowiednie informacje na ten temat znaleźć można w innych tekstach opublikowanych w tym tomie (por. artykuły Zofii Rudnik-Karwatowej, Zenona Mikosa, Pawła Kowalskiego), a także m.in. w innych pracach Zofii Rudnik-Karwatowej, Pawła Kowalskiego czy Zenona Mikosa (Bojar \& Rudnik-Karwatowa, 1998; Rudnik-Karwatowa, 2002a, 2002b; Rudnik-Karwatowa, Mikos \& Bojar, 2007). Chciałabym zwrócić uwagę na jeden tylko, ale bardzo istotny, aspekt systemu iSybislaw - ekwiwalencję słów kluczowych ${ }^{5}$, czyli problemy związane z optymalizacją wyszukiwania w systemie słów kluczowych w różnych językach, co wymaga ustalania odpowiedników polskich słów kluczowych w językach słowiańskich i języku angielskim. Zbudowanie wielojęzycznego słownika słów kluczowych jest jednym z głównych dalekosiężnych zadań międzynarodowego zespołu językoznawców slawistów współpracujących z CSIN nad rozwijaniem systemu iSybislaw.

„Słowa kluczowe to elementarne wyrażenia języka słów kluczowych, równokształtne z terminami, ważnymi i charakterystycznymi dla danej dziedziny wiedzy oraz mogącymi reprezentować treść dokumentu" (SSKJS, 1999, s. 5). Są one elementarnymi jednostkami języka informacyjno-wyszukiwawczego ułatwiającymi korzystanie z systemu iSybislaw (ibidem) - bazy danych, w której zarejestrowanych i udostępnionych online jest obecnie (luty 2014 r.) ponad 18000 dokumentów, 9500 osób (autorów, redaktorów, edytorów, tłumaczy i in.) i 16500 słów kluczowych 6 .

Przed przystąpieniem do dalszej analizy wstępnie należy sprecyzować stosunek między słowami kluczowymi i terminami. Cytowany wyżej Słownik słów kluczowych językoznawstwa slawistycznego (SSKJS) zbudowany był w swej wersji pierwotnej na podstawie ekscerpcji odpowiednich jednostek leksykalnych, z wykorzystaniem tekstów reprezentatywnych dla bieżącej

${ }^{4}$ Historię rozwoju systemu przedstawia Zenon Mikos w artykule opublikowanym w niniejszym tomie.

${ }^{5}$ Problematyka ta była już przedmiotem zainteresowania m.in. Oksany Ostapczuk (2007).

${ }^{6}$ Jeśli uwzględnić nieudostępnione jeszcze online wersje robocze rekordów, liczby te okażą się zdecydowanie większe. Ponadto statystyka nie uwzględnia recenzji, które liczono łącznie z pracami recenzowanymi. 
literatury przedmiotu i ich opisów dokumentacyjnych, oraz na podstawie źródeł leksykograficznych, encyklopedii, tezaurusów, słowników terminologicznych i gramatyk akademickich (SSKJS, 1999, s. 6). Tak więc źródłem jednostek leksykalnych zarejestrowanych w pierwszym wydaniu SSKJS były słowa kluczowe odpowiadające terminom, które odsyłają do rzeczywistości językowej. Założenie, że słowem kluczowym jest słowo z tekstu, które odsyła już do konkretnych tekstów, spowodowało, że liczba jednostek rejestrowanych w systemie iSybislaw znacznie się zwiększyła. Innymi słowy, każdy termin występujący w tekście może zostać wtórnie użyty jako słowo kluczowe w systemie iSybislaw ${ }^{7}$, ale nie każde słowo kluczowe z systemu jest terminem. Por. np. takie słowa kluczowe $\mathrm{z}$ iSybislawa, które nie są terminami językoznawczymi, jak: a) konkretne morfemy, np. bez-, -nik, -uchn-, без-, -тель; b) konkretne leksemy, np. serce, głowa, kot, pies; c) pojęcia, np. 'serce', 'głowa', 'kot', 'pies'; d) tytuły słowników, atlasów, encyklopedii i innych dzieł, np. Słownik języka polskiego XVII i 1. połowy XVIII wieku, Atlas językowy kaszubszczyzny i dialektów sąsiednich, Общеславянский лингвистический атлас, Encyklopedia językoznawstwa ogólnego; e) nazwiska językoznawców slawistów, autorów słowników i dzieł literackich, a także innych osób, np. Baudouin de Courtenay Jan Ignacy Niecisław (1845-1929), Толстой Никита Ильич (1923-1996), Jan Paweł II, papież (1920-2005), Cyryl, św. (827-869). Ustalenie innojęzycznych ekwiwalentów dla wymienionych wyżej słów kluczowych albo jest stosunkowo proste (konkretne leksemy), albo nie jest niezbędne (tytuły słowników i innych dzieł, zwłaszcza nieliterackich, chyba że są to rozpowszechnione przekłady oryginalnych tekstów na inne języki, por. Mistrz i Małgorzata, Czarodziejska góra), albo jest wręcz niewskazane (konkretne morfemy).

Poza wymienionymi wyżej rodzajami słów kluczowych w zasobach systemu iSybislaw pozostaje duży zbiór słów kluczowych równokształtnych z tradycyjnie rozumianymi terminami. Te właśnie jednostki leksykalne będą obiektem analizy w niniejszym omówieniu. Ustalenie dla nich innojęzycznych ekwiwalentów to jedno z tych zadań, które wymaga szczegółowych badań w obrębie poszczególnych języków, a dopiero na następnym etapie - badań porównawczych.

Zakresy pojęć słowo kluczowe i termin tylko w części się pokrywają. W artykule wymiennie stosować będę oba te określenia, cały czas mając na

7 Zasób słów kluczowych odpowiadających terminom w bazie systemu iSybislaw przejęty został na pierwszym etapie ze Słownika słów kluczowych językoznawstwa slawistycznego (SSKJS, 1999). 
uwadze tylko te zbiory jednostek leksykalnych, które są równokształtne. Chciałabym skupić uwagę wyłącznie na kwestii ekwiwalencji międzyjęzykowej, a więc możliwości wyszukiwania w systemie słów kluczowych w różnych językach.

Specyfika terminologii dowolnej nauki - w naszym wypadku językoznawstwa slawistycznego - polega na tym, że nie jest ona wartością stałą. Zasób terminów zmienia się z różnych powodów. Podobnie jak cały język, ulega on zmianom w planie diachronicznym. Pojawiają się nowe kierunki czy dziedziny wiedzy, nasza wiedza o języku jako systemie i konkretnych językach w szczególności jest coraz dokładniejsza, w językoznawstwie - podobnie jak w innych dziedzinach - obserwuje się pewne „mody” i inne. Z punktu widzenia systemu iSybislaw istotniejsze są jednak inne aspekty terminologii językoznawczej. W literaturze lingwistycznej równolegle funkcjonują zarówno internacjonalizmy, czyli terminologia „międzynarodowa” (głównie łacińska), jak i terminologia specyficzna rodzima („narodowa”). I właśnie niektóre problemy związane z relacją między terminami rodzimymi i internacjonalizmami oraz ich wpływ na ustalanie ekwiwalentów słów kluczowych w różnych językach będą przedstawione w dalszej części tekstu. Problem braku odpowiedniości ekwiwalentów terminologicznych szczególnie uwidacznia się w pracach o charakterze konfrontatywnym i typologicznym, co spowodowane jest nie tylko różną strukturą opisywanych języków, lecz także brakiem idealnej symetrii między terminami w różnych narodowych tradycjach gramatycznych ${ }^{8}$. W ostatnich latach pisali o tym m.in. Zuzanna Topolińska $(2009,2010)$ i Włodzimierz Pianka (2009).

Ekwiwalent terminologiczny w językoznawstwie nie jest ekwiwalentem tłumaczeniowym w takim znaczeniu, w jakim traktuje się go w zakresie teorii i praktyki przekładu. Miejscem dla terminów (i to nielicznych) dopiero wtórnie są słowniki przekładowe. Terminy znajdują się przede wszystkim w słownikach terminologicznych oraz specjalistycznych leksykonach i encyklopediach. Dla systemu iSybislaw ekwiwalenty tłumaczeniowe (przekładowe) mogą mieć wyłącznie charakter pomocniczy. Terminów się nie tłumaczy. Terminy się zna! Przy czym ta „znajomość” terminów zawiera w sobie nie tylko samo słowo czy wyrażenie jako takie, lecz także całą siatkę pojęciową, która jemu odpowiada.

Terminologia językoznawcza ukształtowała się na bazie terminów stworzonych do opisu języków klasycznych. Wtórnie była i nadal jest tworzona terminologia rodzima, co skutkuje niejednokrotnie pojawieniem się szeregów synonimicznych

8 Jak słusznie zauważyła Zuzanna Topolińska, „różni autorzy, świadomie lub nieświadomie, używają tych samych terminów w różnym znaczeniu, nierzadko bez definicji” (Topolińska, 2010, s. 216). 
Iwona Łuczków Uwagi o ekwiwalencji słów kluczowych w systemie informacyjnym iSybislaw...

(dubletów) istniejących i funkcjonujących nadal w dokumentach rejestrowanych w iSybislawie ${ }^{9}$. W dokumentach (a więc i w bazie) stosuje się i łacińskie terminy, i ich rodzime ekwiwalenty (por. czas teraźniejszy ${ }^{10} \sim$ ros. настоящее время, презенс, chorw. prezent, czes. prítomný čas, łac. praesens; czas przyszly ros. будущее время, chorw. futur, czes. budoucí čas, łac. futurum; gerundium odsłownik; deiksis pol. wskazywanie, chorw. deiksis, czes. deixe, łac. deixis). Co ciekawe, z czterech wymienionych wyżej preferowanych słów kluczowych dwa to wyrażenia rodzime, a dwa - internacjonalizmy (z polskimi ekwiwalentami - odsłownik, wskazywanie). Problem istnienia synonimów (dubletów) rozwiązano w systemie iSybislaw dzięki zastosowaniu odpowiedniej hierarchii. Terminy preferowane (przyjęte jako podstawowe, zapisywane czcionką półgrubą) są deskryptorami, a terminy niepreferowane (pozostałe terminy występujące w tekstach dokumentów, oznaczone czcionką jasną) - askryptorami ${ }^{11}$. Jako askryptory w systemie traktuje się zarówno dublety terminologiczne w jednym języku, jak i ich innojęzyczne ekwiwalenty. Przyjęte rozwiązanie jest „przyjazne” dla użytkownika, gdyż po wpisaniu dowolnego znanego mu terminu otrzyma on zbiór wszystkich dokumentów zarejestrowanych w systemie z określonym słowem kluczowym.

Na obecnym etapie ustalania ekwiwalencji międzyjęzykowej słowa kluczowe mają w systemie różną liczbę ekwiwalentów. Jednym z najbardziej rozbudowanych jest słowo kluczowe rzeczownik, dla którego zarejestrowane są trzy ekwiwalenty rosyjskie i dwa angielskie oraz kilka w innych językach (por. rys. 1$)^{12}$.

9 Sytuacja ta w zakresie białoruskiej terminologii językoznawczej przedstawiona została w artykule Jauhenii Wołkawej (2013).

10 Dla rozróżnienia słów kluczowych preferowanych (deskryptorów) i niepreferowanych (askryptorów) zastosowano w iSybislaw różne rodzaje pisma. Deskryptory zapisywane są pismem półgrubym, askryptory - jasnym. Ten sam sposób zapisu zastosowany został w niniejszym artykule.

$11 \mathrm{Z}$ problemem wariantów terminologicznych spotykamy się również na poziomie opisu jednego języka, por. polskie terminy tryb przypuszczający i tryb warunkowy. Oba te terminy występują we współczesnych pracach polonistycznych, por. np. Morfologia (1999, ss. 185-187) - tryb przypuszczajacy, Tokarski (2001, s. 201) - tryb przypuszczajacy (warunkowy), Bańko (2002, s. 161) - tryb warunkowy (zwany także przypuszczającym). Również w dwóch wydanych w ostatnich latach słownikach gramatycznych polszczyzny mamy różne określenia tego trybu: SFJP (2001) - tryb przypuszczajaccy, SGJP (2007) - tryb warunkowy. Oba te terminy jako słowa kluczowe zarejestrowane są również w iSybislawie (z różnymi ekwiwalentami rosyjskimi). Dokładniejsza analiza tego problemu wykracza poza ramy nakreślone w tym artykule.

12 iSybislaw nie jest systemem zamkniętym. Na bieżąco wpisywane są kolejne rekordy, a co się z tym wiąże również nowe słowa kluczowe i ich niepreferowane ekwiwalenty. Na rysunkach przedstawiono stan aktualny na 22 marca $2014 \mathrm{r}$. 
Iwona Łuczków Uwagi o ekwiwalencji słów kluczowych w systemie informacyjnym iSybislaw...

\begin{tabular}{|c|c|}
\hline rzeczownik & polski (pol) \\
\hline имя существительное & rosyjski (rus) \\
\hline субстантив & rosyjski (rus) \\
\hline существительное & rosyjski (rus) \\
\hline noun & angielski (eng) \\
\hline substantive & angielski (eng) \\
\hline назоўнік & białoruski (bel) \\
\hline imenica & chorwacki $(\mathrm{scr})$ \\
\hline substantivum & czeski (cze) \\
\hline substantivum & łaciński (lat) \\
\hline samostalnik & słoweński (slv) \\
\hline іменник & ukraiński (ukr) \\
\hline
\end{tabular}

Rys. 1. Niepreferowane ekwiwalenty słowa kluczowego rzeczownik

Oprócz słowa kluczowego rzeczownik w systemie zarejestrowane są jako preferowane słowa kluczowe również konkretne rodzaje rzeczowników (rys. 2), z których wszystkie mogą mieć niepreferowane ekwiwalenty.

\begin{tabular}{|c|c|}
\hline rzeczownik & polski (pol) \\
\hline rzeczownik abstrakcyjny & polski (pol) \\
\hline rzeczownik defektywny & polski (pol) \\
\hline rzeczownik denominalny & polski (pol) \\
\hline rzeczownik dewerbalny & polski (pol) \\
\hline rzeczownik konkretny & polski (pol) \\
\hline rzeczownik nieodmienny & polski (pol) \\
\hline rzeczownik nieosobowy & polski (pol) \\
\hline rzeczownik nieżywotny & polski (pol) \\
\hline rzeczownik odczasownikowy & polski (pol) \\
\hline rzeczownik odimienny & polski (pol) \\
\hline rzeczownik odprzymiotnikowy & polski (pol) \\
\hline rzeczownik odrzeczownikowy & polski (pol) \\
\hline rzeczownik osobowy & polski (pol) \\
\hline rzeczownik pospolity & polski (pol) \\
\hline rzeczownik prefiksalny & polski (pol) \\
\hline rzeczownik zbiorowy & polski (pol) \\
\hline
\end{tabular}

Rys. 2. Preferowane słowa kluczowe odnoszące się do rzeczownika 
Iwona Łuczków Uwagi o ekwiwalencji słów kluczowych w systemie informacyjnym iSybislaw...

Inny problem związany z ekwiwalencją wyszukiwawczą ilustruje termin participium, któremu w polskiej tradycji gramatycznej odpowiada termin imiesłów. Chociaż w systemie iSybislaw preferowane słowo kluczowe podaje się obecnie w języku polskim ${ }^{13}$, świadomie używam łacińskiego terminu, gdyż języki słowiańskie są pod tym względem bardzo zróżnicowane. Ujawnia się to również w zakresie terminologii, co odzwierciedlone jest w bazie, do której przeniesione są słowa kluczowe $\mathrm{z}$ tekstów. Lista zarejestrowanych obecnie w systemie preferowanych słów kluczowych odnoszących się do imiesłowu wygląda następująco (rys. 3):

\begin{tabular}{|c|c|}
\hline imiesłów & polski (pol) \\
\hline imiesłów -t-/-lowy & polski (pol) \\
\hline imiesłów przeszły na $-f-/-/-$ & polski (pol) \\
\hline imiesłów przymiotnikowy & polski (pol) \\
\hline imiesłów przymiotnikowy bierny & polski (pol) \\
\hline imiesłów przymiotnikowy czynny & polski (pol) \\
\hline imiesłów przymiotnikowy czynny czasu przeszłego dokonanego & polski (pol) \\
\hline imiesłów przymiotnikowy czynny czasu przeszłego niedokonanego & polski (pol) \\
\hline imiesłów przysłówkowy & polski (pol) \\
\hline imiesłów przysłówkowy uprzedni & polski (pol) \\
\hline imiesłów przysłówkowy współczesny & polski (pol) \\
\hline imię & polski (pol) \\
\hline imie & polski (pol) \\
\hline imię chrzestne & polski (pol) \\
\hline imię dwuczłonowe & polski (pol) \\
\hline imię męskie & polski (pol) \\
\hline imię obce & polski (pol) \\
\hline imię osobowe & polski (pol) \\
\hline imię własne & polski (pol) \\
\hline imię zakonne & polski (pol) \\
\hline
\end{tabular}

Rys. 3. Preferowane słowa kluczowe odnoszące się do imiesłowu

Większość z tych słów kluczowych ma również różnojęzyczne niepreferowane ekwiwalenty (por. rys. 4).

${ }^{13}$ Docelowo słowa kluczowe we wszystkich językach będą równoprawne. 
Iwona Łuczków Uwagi o ekwiwalencji słów kluczowych w systemie informacyjnym iSybislaw...

\begin{tabular}{|c|c|}
\hline imiesłów przymiotnikowy & polski $(\mathrm{pol})$ \\
\hline причастие & rosyjski (rus) \\
\hline participle & angielski (eng) \\
\hline дзеепрыметнік & białoruski (bel) \\
\hline participium & czeski (cze) \\
\hline participium & łaciński (lat) \\
\hline дієприкметник & ukraiński (ukr) \\
\hline imiesłów przymiotnikowy bierny & polski (pol) \\
\hline страдательное причастие & rosyjski (rus) \\
\hline přičestí trpné & czeski (cze) \\
\hline imiesłów przymiotnikowy czynny & polski (pol) \\
\hline действительное причастие & rosyjski (rus) \\
\hline активний дієприкметник & ukraiński (ukr) \\
\hline imiesłów przymiotnikowy czynny czasu przeszłego dokonanego & polski (pol) \\
\hline past active aorist participle & angielski (eng) \\
\hline минало свършено деятелно причастие & bułgarski (bul) \\
\hline imiesłów przymiotnikowy czynny czasu przeszłego niedokonanego & polski (pol) \\
\hline минало несвършено деятелно причастие & bułgarski (bul) \\
\hline imiesłów przysłówkowy & polski (pol) \\
\hline деепричастие & rosyjski (rus) \\
\hline adverbial participle & angielski (eng) \\
\hline prechodnik & czeski (cze) \\
\hline дієприслівник & ukraiński (ukr) \\
\hline imiesłów przysłówkowy uprzedni & polski (pol) \\
\hline деепричастие прошедшего времени & rosyjski (rus) \\
\hline prechodnik minulý & czeski (cze) \\
\hline imiesłów przysłówkowy współczesny & polski (pol) \\
\hline деепричастие настоящего втемени & rosyjski (rus) \\
\hline přechodník prìtomný & czeski (cze) \\
\hline
\end{tabular}

Rys. 4. Niepreferowane ekwiwalenty słów kluczowych odnoszące się do imiesłowu

Dla pełności opisu listę słów kluczowych związanych z imiesłowami należy uzupełnić o słowo kluczowe forma $\boldsymbol{n a}$ - $\boldsymbol{t}$-/-l- z odpowiadającymi mu niepreferowanymi ekwiwalentami (rys. 5).

\begin{tabular}{|c|c|}
\hline forma na $-t-1-$ & polski (pol) \\
\hline forma -t-l-towa & polski (pol) \\
\hline imiesłów -t-/-towy & polski (pol) \\
\hline imiesłów przeszły na $-1-1-1-$ & polski (pol) \\
\hline príčestí Lové & czeski (cze) \\
\hline príčestí minulé & czeski (cze) \\
\hline
\end{tabular}

Rys. 5. Słowo kluczowe forma na - $\boldsymbol{t}-/-\boldsymbol{l}$ - z ekwiwalentami 
Iwona Łuczków Uwagi o ekwiwalencji słów kluczowych w systemie informacyjnym iSybislaw...

Najszerszy zakres z wymienionych wyżej słów kluczowych ma imiesłów. Jednak bez dookreśleń trudno ustalić, czy w tekście mowa o imiesłowach przymiotnikowych i przysłówkowych, i o których z nich. Jedynie opis bibliograficzny tekstów traktujących o wszystkich typach imiesłowów należałoby opisać słowem kluczowym imiesłów. Bardziej skonkretyzowane są słowa kluczowe imiesłów przymiotnikowy i imiesłów przysłówkowy. Jednak i w tym przypadku nie jest to jednoznaczne terminologicznie. Języki słowiańskie są bowiem również w tym zakresie zróżnicowane. W niektórych występują współcześnie tylko imiesłowy przymiotnikowe czynne i bierne (np. polski), w innych jest jeszcze rozróżnienie imiesłowów przymiotnikowych czasu przeszłego i czasu teraźniejszego (np. rosyjski). Jeszcze bardziej skomplikowane okazuje się to w języku bułgarskim (por. ekwiwalenty bułgarskie na rys. 4). Zróżnicowanie systemów gramatycznych słowiańszczyzny widać również w zakresie imiesłowów przysłówkowych. W niektórych językach są dwie takie formy czasownika (np. polski, rosyjski), w innych formalnie tylko jedna (np. macedoński). Poza tym ponieważ $\mathrm{w}$ iSybislawie rejestrowane są również prace dotyczące diachronii, nie można ograniczać słów kluczowych odzwierciedlających wyłącznie współczesny stan języków słowiańskich.

Problem ekwiwalencji terminologicznej pogłębia się, jeśli spojrzymy na funkcjonowanie imiesłowów w zdaniu. W zależności od tradycji opisu konstrukcje z imiesłowami przysłówkowymi traktowane są na pierwszy rzut oka sprzecznie: albo jako zdanie złożone (polski: zdanie złożone z imiesłowowym równoważnikiem zdania), albo jako zdanie proste rozwinięte (rosyjski: простое предложение осложненной структуры). Niepreferowane ekwiwalenty słowa kluczowego imiesłowowy równoważnik zdania przedstawione są na rys. 6.

\begin{tabular}{lc}
\hline Słowo & Język \\
\hline imiesłowowy równoważnik zdania & polski (pol) \\
\hline деепричастная конструкция & rosyjski (rus) \\
\hline деепричастный оборот & rosyjski (rus) \\
незалежна дієприкметникова конструкція & ukraiński (ukr) \\
\hline
\end{tabular}

Rys. 6. Niepreferowane ekwiwalenty słowa kluczowego imiestowowy równoważnik $z d a n i a$

Przy omówieniu słów kluczowych związanych z terminem imiesłów warto odnotować jeszcze ekwiwalenty rosyjskiego słowa kluczowego причастный оборот (por. rys. 7). 
Iwona Łuczków Uwagi o ekwiwalencji słów kluczowych w systemie informacyjnym iSybislaw...

\begin{tabular}{ll}
\hline Słowo & Język \\
\hline причастный оборот & rosyjski (rus) \\
\hline konstrukcja z imiesłowem przymiotnikowym & polski (pol) \\
\hline независимая причастная конструкция & rosyjski (rus) \\
\hline
\end{tabular}

Rys. 7. Niepreferowane ekwiwalenty słowa kluczowego причастный оборот

Zadaniem indeksatora opracowującego konkretny dokument jest podanie w sposób odpowiedzialny i merytorycznie poprawny zbioru słów kluczowych relewantnych do treści dokumentu. Ponadto przynajmniej w jakimś stopniu powinien on przewidzieć potrzeby i zachowanie użytkownika systemu oraz uwzględnić jego nawyki wyszukiwawcze. Czego innego i inaczej będą szukali naukowiec, doktorant i student. Konkretny użytkownik systemu w wyszukiwaniu albo będzie wykorzystywał znane mu wcześniej terminy, którymi posługuje się w swojej pracy, albo też będzie poszukiwał informacji w swoim języku etnicznym. Przytoczone wyżej przykłady pokazują, że opis konkretnych dokumentów nie powinien być zbyt głęboki, ale i nie zbyt ogólny, bo powstanie szum informacyjny. Najbardziej adekwatną informację uzyskałby użytkownik, wpisując słowo kluczowe imiesłów, a następnie przeprowadzając selekcję otrzymanych wyników. $\mathrm{Na}$ tej podstawie mógłby zdecydować, jakie dokumenty go interesują, które są relewantne dla jego potrzeb. W takim wypadku w opisie wszystkich dokumentów traktujących o jakichkolwiek typach imiesłowów musiałoby pojawić się słowo kluczowe imiestów z ewentualną konkretyzacją przy pomocy dodatkowych słów kluczowych (np. imiesłów przymiotnikowy czy imiesłów przysłówkowy wspótczesny). Jeśli informacja w rekordzie będzie zbyt szczegółowa, to jest duże prawdopodobieństwo, że dokumenty opisane słowem kluczowym o szerszym zakresie umkną uwadze użytkownika przy wyszukiwaniu. Segregację wyselekcjonowanych rekordów ułatwia w procesie wyszukiwania tzw. KOszYK, w którym można zapisywać wybrane rekordy, a następnie, po dokładniejszym zapoznaniu się z opisem rekordów, z niektórych ewentualnie zrezygnować. To wygodny dla użytkownika sposób likwidacji szumu informacyjnego.

Międzynarodowy zespół lingwistów współpracujących z CSIN nad ustalaniem innojęzycznych ekwiwalentów słów kluczowych w systemie iSybislaw próbuje uporządkować funkcjonującą w literaturze slawistycznej terminologię językoznawczą. Praca ta nie jest prosta, wymaga dobrej znajomości różnojęzycznej literatury, częstych dyskusji i konsultacji w ramach zespołu. Proponowane w systemie ekwiwalenty słów kluczowych równokształtnych z terminami mogą stanowić bazę danych, pełniącą funkcję słownika terminologicznego 
z zakresu językoznawstwa slawistycznego. Zbudowanie takiego wielojęzycznego słownika jest ważne nie tylko dla językoznawstwa teoretycznego, lecz także dla wymagających znakowania morfosyntaktyczngo korpusów językowych (zwłaszcza korpusów równoległych, paralelnych).

Przedstawiony w artykule ogólny zarys problemów związanych z ustalaniem ekwiwalencji słów kluczowych w systemie iSybislaw skłania do sformułowania podstawowego wniosku. Tworzeniem słownika słów kluczowych z zakresu językoznawstwa slawistycznego w różnych językach na potrzeby systemu iSybislaw (a przynajmniej jego weryfikacją) powinni zajmować się specjaliści w zakresie poszczególnych działów językoznawstwa (fonetyki, morfologii, składni, słowotwórstwa, dialektologii, onomastyki, frazeologii, etnolingwistyki i in.). Wcześniej jednak należy zbadać i uporządkować terminologię w zakresie każdej z poddyscyplin językoznawstwa slawistycznego w obrębie poszczególnych języków, a dopiero na następnym etapie można przeprowadzić badania porównawcze. Ze względu na to, że na pierwszym etapie tworzenia systemu iSybislaw przyjęto zasadę, że deskryptorami są słowa kluczowe w języku polskim i do nich dołączane są ekwiwalenty w innych językach, najlepiej byłoby, gdyby uczestniczący w projekcie językoznawcy zajmowali się konfrontacją polsko-innosłowiańską. Dopiero taka „specjalizacja” daje większą pewność, że osoba ustalająca odpowiedniki zna różne tradycje opisu, co pozwoli w przyszłości uniknąć większej liczby błędów wynikających z różnego zakresu terminów (por. pol. $z$ danie $\sim$ ros. предложение) lub braku odpowiedniego terminu w innym języku (por. pol. podmiot domyślny - ros. ?; równoważnik zdania - ros. ?; ros. npocmopeuue - pol. ?). Usystematyzowanie terminologiczne powinno odbyć się dla każdego z języków niezależnie, a dopiero wtórnie - na poziomie wielu języków. Docelowo słowa kluczowe we wszystkich językach słowiańskich i w języku angielskim będą traktowane w systemie iSybislaw równoprawnie, a wyszukiwanie można będzie przeprowadzać w dowolnym $\mathrm{z}$ tych języków. Należy jednak mieć świadomość, że ten wielojęzyczny słownik będzie mieć raczej charakter słownika słów kluczowych mającego specjalną funkcję informacyjno-wyszukiwawczą w zakresie językoznawstwa slawistycznego, a nie definitywnych rozstrzygnięć terminologicznych. Tym bardziej, że w perspektywie wielu lat najprawdopodobniej zmieni się sposób myślenia zarówno o terminach jako takich, jak i o słowach kluczowych w szczególności ${ }^{14}$.

\footnotetext{
${ }^{14}$ Por. na temat artykuł Wiesława Babika w niniejszym tomie.
} 
Iwona Łuczków Uwagi o ekwiwalencji słów kluczowych w systemie informacyjnym iSybislaw...

Przedstawione w artykule problemy nie wyczerpują całej złożoności zagadnienia. Niewątpliwie tekst wzbogaciłoby zbadanie korelacji między słowami kluczowymi rodzimymi i zapożyczonymi (zwrócił na to uwagę jeden $\mathrm{z}$ recenzentów). Wymagałoby to m.in. określenia zakresu terminów „obcych” (zapożyczenia, terminy zaadaptowane, kalki itp.). Zadanie to wykracza jednak poza ramy nakreślone dla niniejszego artykułu.

Wskazane wyżej problemy, które mają twórcy i indeksatorzy systemu iSybislaw, będą sukcesywnie rozwiązywane. iSybislaw to pierwsze tak szeroko zakrojone przedsięwzięcie z zakresu bibliografii światowego językoznawstwa slawistycznego. Wśród podstawowych zalet internetowej wersji bibliografii należy wyróżnić to, że o ile wersja książkowa jest w zasadzie wersją ostateczną (ewentualne erraty i korekty merytoryczne są skomplikowane), o tyle bardziej lub mniej przypadkowe błędy, które pojawić się mogą w systemie iSybislaw, są na bieżąco korygowane. System jest i będzie jednak udoskonalany wraz z pojawiającymi się nowymi możliwościami technicznymi.

\section{Bibliografia}

Bańko, M. (2002). Wykłady z polskiej fleksji. Warszawa: PWN.

Bibliograficzna baza danych światowego językoznawstwa slawistycznego iSybislaw. (b.d.). Pobrano 22 marca 2014, z http://www.isybislaw.ispan.waw.pl

Bojar, B., \& Rudnik-Karwatowa, Z. (1998). Koncepcja nowoczesnego systemu informacji slawistycznej. W H. Dalewska-Greń, J. Rusek, \& J. Siatkowski (Kom. Red.), Językoznawstwo. Prace na XII Międzynarodowy Kongres Slawistów w Krakowie 1998 (ss. 41-47). Warszawa: Energeia. (Z Polskich Studiów Slawistycznych; seria 9).

Grzegorczykowa, R., Laskowski, R., \& Wróbel, H. (Red.). (1999). Gramatyka współczesnego jezyka polskiego: morfologia [Morfologia]. Warszawa: PWN.

Lubaszewski, W., Wróbel, H., Gajęcki, M., Moskal, B., Orzechowska, A., Pietras, P., \& Rokicka, T. (2001). Stownik fleksyjny języka polskiego [SFJP] [CD ROM]. Warszawa: Wydawnictwo Prawnicze LexisNexis.

Ostapczuk, O. (2007). Język informacyjno-wyszukiwawczy i problem ekwiwalencji słów kluczowych językoznawstwa slawistycznego. Zagadnienia Informacji Naukowej, 2, 54-63.

Pianka, W. (2009). Nieścisłości związane z terminem „kategoria” w polskiej i słowiańskiej teorii lingwistycznej. W M. Cichońska (Red.), Kategorie w języku: język w kategoriach (ss. 11-23). Katowice: Wydawnictwo Uniwersytetu Şląskiego.

Rudnik-Karwatowa, Z. (2002a). Język informacyjno-wyszukiwawczy dokumentacyjnego systemu językoznawstwa slawistycznego: doświadczenia z realizacji projektu. W H. Popowska- 
Iwona Łuczków Uwagi o ekwiwalencji słów kluczowych w systemie informacyjnym iSybislaw...

-Taborska, Z. Rudnik-Karwatowa, J. Rusek, \& J. Siatkowski (Kom. Red.), Językoznawstwo. Prace na XIII Międzynarodowy Kongres Slawistów w Lublanie 2003 (ss. 207-212). Warszawa: Komitet Słowianoznawstwa PAN. (Z Polskich Studiów Slawistycznych; seria 10).

Rudnik-Karwatowa, Z. (2002b). Słowa kluczowe - elementarne jednostki leksykalne języka informacyjno-wyszukiwawczego. W A. Pstyga, \& K. Szcześniak (Red.), Słowo z perspektywy językoznawcy i tłumacza (ss. 13-18). Gdańsk: Wydawnictwo Uniwersytetu Gdańskiego.

Rudnik-Karwatowa, Z., \& Karpińska, H. (1999). Słownik słów kluczowych językoznawstwa slawistycznego [SSKJS]. Warszawa: Slawistyczny Ośrodek Wydawniczy.

Rudnik-Karwatowa, Z., Mikos, Z., \& Bojar, J. (2007). Nowoczesny system informacji slawistycznej. Zadania, dotychczasowe wyniki i perspektywy. Zagadnienia Informacji Naukowej, 2, 19-40.

Ruszkowski, M. (2001). Relacja między pojęciami „zdanie nierozwinięte” - „zdanie rozwinięte” w modelu składni tradycyjnej. Język Polski, (1-2), 76-81.

Saloni, Z., Gruszczyński, W., Woliński, M., \& Wołosz, R. (2007). Słownik gramatyczny języka polskiego [SGJP] [CD ROM]. Warszawa: Wiedza Powszechna.

Tokarski, J. (2001). Fleksja polska. Warszawa: PWN.

Topolińska, Z. (2009). Kilka słów o naszej siatce pojęciowej i terminologicznej. W J. Mindak-Zawadzka, \& I. M. Doliński (Red.), Językowy świat Słowian: zjawiska, interpretacje, znaki zapytania: ksiega jubileuszowa na 70-lecie Profesora Włodzimierza Pianki (ss. 209-214). Warszawa: Uniwersytet Warszawski. Wydział Polonistyki; Instytut Slawistyki Zachodniej i Południowej.

Topolińska, Z. (2010). O tradycji w nauce. W Ј. Грковић-Мејџор, \& М. Радовановић (Red.), Теорија дијахронијске тингвистике и проучаваюе словенских језика (ss. 215-221). Београд: Српска академија наука и уметности. Одељење језика и књижевности. („Српски језик у светлу савремених лингвистичких теорија”; књ. 4).

Wołkava, J. (2013). Праблемы беларускай лінгвістычнай тэрміналогіi і пытанне суадноснасці ключавых слоў (лінгвістычных тэрмінаў) у iSybislaw. Slavia Orientalis, 62(2), 285-292.

\section{Bibliography (transliteration)}

Bańko, M. (2002). Wykłady z polskiej fleksji. Warszawa: PWN.

Bibliograficzna baza danych światowego językoznawstwa slawistycznego iSybislaw. (n.d.). Retrieved March 22, 2014, from http://www.isybislaw.ispan.waw.pl

Bojar B., \& Rudnik-Karwatowa Z. (1998). Koncepcja nowoczesnego systemu informacji slawistycznej. In H. Dalewska-Greń, J. Rusek, \& J. Siatkowski (Eds.), Językoznawstwo. Prace na XII Międzynarodowy Kongres Slawistów w Krakowie 1998 (pp. 41-47). Warszawa: Energeia. (Z Polskich Studiów Slawistycznych; seria 9). 
Iwona Łuczków Uwagi o ekwiwalencji słów kluczowych w systemie informacyjnym iSybislaw...

Grzegorczykowa, R., Laskowski, R., \& Wróbel, H. (Eds.). (1999). Gramatyka współczesnego języka polskiego: morfologia [Morfologia]. Warszawa: PWN.

Lubaszewski, W., Wróbel, H., Gajęcki, M., Moskal, B., Orzechowska, A., Pietras, P., \& Rokicka, T. (2001). Słownik fleksyjny języka polskiego [SFJP] [CD ROM]. Warszawa: Wydawnictwo Prawnicze LexisNexis.

Ostapczuk, O. (2007). Język informacyjno-wyszukiwawczy i problem ekwiwalencji słów kluczowych językoznawstwa slawistycznego. Zagadnienia Informacji Naukowej, 2, 54-63.

Pianka, W. (2009). Nieścisłości związane z terminem „kategoria” w polskiej i słowiańskiej teorii lingwistycznej. In M. Cichońska (Ed.), Kategorie w języku: język w kategoriach (pp. 11-23). Katowice: Wydawnictwo Uniwersytetu Śląskiego.

Rudnik-Karwatowa, Z. (2002a). Język informacyjno-wyszukiwawczy dokumentacyjnego systemu językoznawstwa slawistycznego: doświadczenia $\mathrm{z}$ realizacji projektu. In H. Popowska-Taborska, Z. Rudnik-Karwatowa, J. Rusek, \& J. Siatkowski (Eds.), Językoznawstwo. Prace na XIII Międzynarodowy Kongres Slawistów w Lublanie 2003 (pp. 207-212). Warszawa: Komitet Słowianoznawstwa PAN. (Z Polskich Studiów Slawistycznych; seria 10).

Rudnik-Karwatowa, Z. (2002b). Słowa kluczowe - elementarne jednostki leksykalne języka informacyjno-wyszukiwawczego. In A. Pstyga, \& K. Szcześniak (Eds.), Słowo z perspektywy językoznawcy i tłumacza (pp. 13-18). Gdańsk: Wydawnictwo Uniwersytetu Gdańskiego.

Rudnik-Karwatowa, Z., \& Karpińska, H. (1999). Słownik słów kluczowych językoznawstwa slawistycznego [SSKJS]. Warszawa: Slawistyczny Ośrodek Wydawniczy.

Rudnik-Karwatowa, Z., Mikos, Z., \& Bojar, J. (2007). Nowoczesny system informacji slawistycznej. Zadania, dotychczasowe wyniki i perspektywy. Zagadnienia Informacji Naukowej, 2, 19-40.

Ruszkowski, M. (2001). Relacja między pojęciami „zdanie nierozwinięte” - „zdanie rozwinięte” w modelu składni tradycyjnej. Język Polski, (1-2), 76-81.

Saloni, Z., Gruszczyński, W., Woliński, M., \& Wołosz, R. (2007). Słownik gramatyczny języka polskiego [SGJP] [CD ROM]. Warszawa: Wiedza Powszechna.

Tokarski, J. (2001). Fleksja polska. Warszawa: PWN.

Topolińska, Z. (2009). Kilka słów o naszej siatce pojęciowej i terminologicznej. In J. Mindak-Zawadzka, \& I. M. Doliński (Eds.), Językowy świat Słowian: zjawiska, interpretacje, znaki zapytania: ksiega jubileuszowa na 70-lecie Profesora Włodzimierza Pianki (pp. 209-214). Warszawa: Uniwersytet Warszawski. Wydział Polonistyki; Instytut Slawistyki Zachodniej i Południowej.

Topolińska, Z. (2010). O tradycji w nauce. In J. Grković-Mejdžor, \& M. Radovanović (Eds.), Teorija dijahronijske lingvistike i proučavanje slovenskih jezika (pp. 215-221). Beograd: Srpska akademija nauka i umetnosti. Odeljenje jezika i književnosti. („Srpski jezik u svetlu savremenih lingvističkih teorija”; knj. 4).

Volkava, J. (2013). Prablemy belaruskaŭ linhvistychnaŭ tėrminalogii i pytanne suadnosnastsi kliuchavykh sloŭ (linhvistychnykh tèrminaŭ) u iSybislaw. Slavia Orientalis, 62(2), 285-292. 


\section{Some remarks on the equivalence keywords in the iSybislaw system information (based on selected grammatical terms)}

\section{Summary}

The article focuses on one of the issues connected with the development of the information retrieval system iSybislaw. The system contains a biographical database of Slavic linguistics which is available on-line at www.isybislaw.ispan. waw.pl. An important element of the system are key words, and the main aim of the international team of Slavist linguists developing the iSybislaw system in cooperation with the Slavic Academic Information Centre (CSIN) is to create a multilingual dictionary of terms related to various areas of Slavic linguistics, that is to establish terminological equivalents in Slavic languages and in the English language. Establishing multilingual terminological equivalents is essential not only for Slavic theoretical linguistics but also for language corpora which require morphosyntactic marking, especially parallel corpora. The analysis presented here allows for drawing the conclusion that the dictionary of multilingual key terms of Slavic linguistics for the iSybislaw system should be developed (or at least verified) by specialists in individual areas of Slavic linguistics (phonetics, morphology, syntax, word formation, dialectology, ethnolinguistics, etc.). Because of the adopted principle that Polish keywords are used as descriptors in the iSybislaw system, the linguists should compare the Polish system of terms with the terminology used in other Slavic languages. Thanks to such "specialization" we could be quite sure that the person establishing the equivalents knows various descriptive traditions of linguistics, and in the future this would allow us to avoid many of the mistakes connected with the differences in the range of the term or the lack of appropriate equivalent in another language.

Keywords: bibliographic database; interlingual equivalence; iSybislaw; keyword; linguistic terminology; Slavic languages; term

Słowa kluczowe: bibliograficzna baza danych; ekwiwalencja międzyjęzykowa; iSybislaw; języki słowiańskie; słowo kluczowe; termin; terminologia językoznawcza 